\title{
Historical and Empirical Basis for Communal Title in Minerals at the National Level: Does Ownership Matter for Human Development?
}

\author{
Gary Flomenhoft ${ }^{\mathbb{D}}$ \\ Center for Social Responsibility in Mining, Sustainable Minerals Institute, University of Queensland, St. Lucia, \\ QLD 4067, Australia; g.flomenhoft@uq.edu.au, Tel.: +61-(0)4-3898-4818 \\ Received: 30 April 2018; Accepted: 5 June 2018; Published: 11 June 2018 \\ check for \\ updates
}

\begin{abstract}
This paper explores the impact of mineral ownership on the resource curse as measured by the Human Development Index. We start from the basic assumption that the Earth and its minerals are common pool resources, and the sharing of benefits would improve development outcomes. Communal title to minerals exists at the international level for the deep seabed, outer space objects, and, potentially Antarctica, and at the sub-national level through communal title to land, such as traditional landowners and aboriginal tribes. A comprehensive summary of national mining title laws for 199 countries was completed in order to determine if communal ownership is recognized at the national level. The finding is that this type of ownership is non-existent at the national level. The methods include historiography, extensive compilation of national constitutions and mining laws, and linear regression analysis. Ownership titles were combined into centralized and decentralized categories, and simple regression conducted to determine correlation with the human development index (HDI) for 199 countries. Initial findings are that decentralized mineral ownership titles are statistically correlated with higher HDI outcomes.
\end{abstract}

Keywords: communal title; commonwealth; mineral title; national mineral title; mineral rights; national mining laws; communal property titles; human development index; HDI; common heritage of mankind; communal ownership; public trust doctrine; sovereign wealth fund; communal property rights

\section{Introduction}

\subsection{What is the Economic Commonwealth in the Mining Sector?}

Although "commonwealth" is normally defined in political terms, it literally means common property or riches [1]. Therefore, commonwealth is also economic. We start from the basic assumption that the Earth and its minerals are common pool resources. In the mining sector, we are defining commonwealth by communal title to minerals. The term "title" or "ultimate title" is used here to refer to the ultimate owner of a resource, in this case minerals. This paper explores the empirical and legal history of communal title to minerals, and development outcomes in various mineral title regimes.

\subsection{Research Question and Methods}

The general hypothesis is that communal ownership of minerals will have better development outcomes due to the broader distribution of benefits, by redirecting benefits to the populace instead of to the state. In order to answer this question we must first establish if communal ownership can be legally and historically justified. We explore the historiography of property rights, in general, and mineral titles, in particular. We look at the history of mineral titles from Rome to recent 
times, and explore communal property in western thought. Modern systems of communal property rights are explored looking at supra-national and sub-national property laws. Next, we determine if communal title exists at the national level by conducting a comprehensive summary and categorization of national mineral title laws for 199 countries. We establish seven different categories of ownership: No minerals, President or Ruler, State or Crown, Communal (People/Common/Collective), "Customary" Landowners, Decentralized/Mixed, and Claimant/Ownerless/Landowner. We find that communal ownership of minerals essentially does not exist at the national level, except in legal rhetoric. Therefore, we modified our research question to look at the impact of mineral ownership, in general, on the Human Development Index (HDI). We looked at the impact of the national mineral ownership category on the HDI using linear regression analysis. We found that individual categories had inadequate sample sizes, so we were unable to determine a statistical relationship. Therefore, we combined the samples into two larger categories of centralized and decentralized ownership, and performed a comparison of the means. This provides empirical evidence for the benefit of decentralized over centralized governance, which can also be found in the literature by Farzanegan, et al. [2], Weinthal and Luong [3], and others. The article addresses the question of mineral ownership, which has rarely been addressed in the literature. It provides the only complete list of national mineral ownership available, and adds to the literature on centralized versus decentralized mineral governance. This is important for sustainability, for mining governance, and for mitigation of the resource curse which plagues resource-rich developing countries.

\subsection{The Importance of Ownership}

The issue of legal title to minerals and other resource wealth is of great importance, as it has a significant influence on economic development, as well as the distribution of wealth. Luong and Weinthal contend that ownership is usually ignored because researchers make the assumption that minerals are always state-owned [4]. Ownership of minerals is essential to understand who benefits. Cawood and Minnitt contend that the mineral owner is entitled to compensation if minerals are taken by another agent, giving the owner unique rights [5]. Hernando DeSoto in his landmark book, "The Mystery of Capital, Why Capitalism Succeeds in the West and Fails Everywhere Else" claimed that individual property titles were the key to development success [6]. There is currently a great deal of pressure for common pool resources to be privatized due to corporate globalization and the prevailing doctrine of neo-liberalism. The current trend in mineral ownership is mainly to allocate title to the state or "crown" which exists for 142 countries listed below. States are then under intense pressure from corporations to turn over mineral rights with generous concessions. Wegenast and Schneider find that international ownership creates resentment among the local population [7]. Discussion of common or communal rights is almost non-existent at the national level, despite being the primary focus at the international level. A few jurisdictions allocate rights to individuals or claimants, such as the US or Scandinavia.

As it stands now, there is no requirement in any country having national title to minerals to distribute revenue or benefits to local people. Benefit sharing is determined only by the level of democratic participation in government, and the responsiveness of officials to citizens' demands. Even in democracies such as Australia, many people feel that mineral revenue has been squandered, as there is no savings fund for the future when resources become depleted, and massive resource wealth accrues to corporations and individuals [8]. Sovereign wealth funds generate revenue and savings for the state, but provide direct benefits to citizens only in a few rare cases, such as Alaska [9].

Providing legal title of minerals to the entire population, to communities, or individuals could provide a strong counterforce to the centralizing and privatizing tendency of modern states in the globalized era. There is a great deal of literature related to the "common heritage of mankind" (CHM) principle in seabed and outer space law. Thomas Paine suggested that the Earth, itself, is the common property of mankind, and not just deep seabeds or outer space [10]. Hunter-gatherer people traditionally held property in common, not as individuals. The Rirratjingu and the Gumatj clans of 
Australia were apparently able to equitably allocate use of "flints, clays and other useful minerals" on their land ([11], pp. 7-8). Many legal cases discuss the issue of communal native title, and the debate about native title can greatly inform the discussion of national mining title laws.

\subsection{A Short Summary of the "Resource Curse"}

Sachs and Warner in their famous working paper defined the resource curse as the tendency of mineral-exporting countries to have slower economic growth, controlling for other factors [12]. In The Paradox of Plenty: A Meta-Analysis, the authors identify the two major perspectives on the resource curse: Macroeconomic mechanisms, as reflected in the market and the political function of institutions [13]. The market perspective includes the "Dutch disease" (currency inflation resulting in the reduction of non-mineral economy), an over-expanding public sector, non-reinvestment of natural resource rents, and volatility of resource prices. The institutional explanation focusses on rent-seeking behaviour, where due to poor governance or corruption, government officials or entrepreneurs are able to monopolize resource rents for themselves. In this paper, I will be looking at the Human Development Index (HDI) as the indicator of "development", which is a much broader indicator than GDP growth. While HDI includes GDP, it also includes life expectancy and education.

\subsection{The Rentier State Theory of the Resource Curse}

There are numerous theories that try to explain the resource curse according to governance; Mahdevi says that governments try to maximize revenue while minimizing costs, among other explanations [14]. Shambayati claims that the state maximizes its autonomy, while making a segment of the population dependent upon it [15]. Ross contends that if governments can rely mainly on resource rents for revenue: "they are freed from the need to levy domestic taxes and become less accountable to the societies they govern ([16], p. 312)". I consider this the most plausible explanation, and it underlies the analysis in this paper.

According to the 2013 Resource Governance Index, by the Revenue Watch Institute, out of the 58 countries accounting for $80-90 \%$ of world petroleum and mining only 11 , or fewer than $20 \%$, have adequate standards of transparency and accountability ([17], p. 1) reflecting the resource curse. The Resource Governance Index "measures the quality of resource governance in 81 countries that together produce 82 percent of the world's oil, 78 percent of its gas and a significant proportion of minerals, including 72 percent of all copper [18]." Of the 58 countries rated, 27 were rated as authoritarian states by The Economist Intelligence Unit 2014 Democracy Index ([19], pp. 7-8). Yet mining titles are usually allocated to the national government. Sometimes mineral titles belong to a single family, such as the allocation of most shares of the national oil company Aramco to the Saud family of Saudi Arabia, or even to a single individual, the President (Zambia or Zimbabwe). By giving all the mineral ownership rights to a dictator or family, it is not surprising that these countries suffer the resource curse. Therefore, an alternative property ownership regime, like some form of communal property title, might mitigate the resource curse.

\subsection{Sustainability in the Mining Industry}

The International Council on Mining and Metals (ICMM) has determined a framework of 10 principles for sustainable development, including measures to cooperate on sustainable development strategies, respect human rights, minimize involuntary resettlement, improve social performance, partner with government and NGOs, address poverty, and report on performance [20]. All of these goals would be mitigated by reducing or eliminating the resource curse, and increasing the human development index of the target country.

\subsection{Categories of Property Rights in Land}

To begin our investigation into the history of communal property title in minerals, and why it is so rare at the nation-state level, it is first important to understand the basic categories of property. 
This is found in the literature on property rights, such as [21-28]. Fedeer and Feeny ([24], p. 137) provide a summary of the four basic categories of property rights:

- Open access: Rights are not assigned, resulting in no motivation to conserve and resources are often degraded, the so-called "tragedy of the commons", which is actually the "tragedy of open-access".

- Communal property: Exclusive ownership rights are given to a group of individuals, community, corporation, association, or other group.

- State Property: Natural resources are managed by the government or the public sector.

- Private property: Exclusive rights are assigned to individuals.

It is crucial to comprehend the difference between mineral title and mineral rights. Mineral title refers to who has ultimate ownership of subsoil resources, in the commonwealth countries referred to as "radical title" usually by the crown. Mineral "rights" can be granted by the owner of the mineral title to any number of agents, including individuals, corporations, tribes, provinces, etc. Mineral rights can be granted on an inalienable [29] leasehold basis, on an alienable freehold basis, or many other combinations. Therefore, the titleholder has the ultimate sovereignty over the resources, and the ultimate decision-making power.

\section{History of Communal Property Rights}

\subsection{Roman Law-Institutes of Justinian, Ius Gentium (Law of Nations)}

The first comprehensive system of laws was the Institutes of Justinian, compiled by the Roman Emperor Justinian in the sixth century, largely based upon the Institutes of Gaius, a Roman jurist of the second century A.D. ([30], p. vii), [25,26,31-36].

Justinian asserted an "ius gentium", or law of nations, based on what he called, "the source of morality and the true foundation of all civic laws" which contained "the idea of all mankind as forming one natural community of which all are citizens ([31], p. 61)". The concept of a "natural universal law" was later used by enlightenment writers seeking to overturn the authority of the church and, more recently, to promote concepts of international law by the United Nations.

\subsection{Communal Property in Roman Law}

The Codes of Justinian in Roman law established common property of citizens including the "air, running water, the sea, and consequently the shore of the sea" [30]. Roman law distinguished between res publica (state property), res privatae (private property), as well as two categories of common property: res communes (open access), and res universitatis (community property). They also had the category of res nullius, the property of no one [30].

Larschan and Brennan ([37], p. 315) explain the difference between res nullius and res communis, as follows:

- Res nullius: Things that belong to no one but can be appropriated. It means the same as open access. The doctrine of res nullius was used by Western Europeans as a basis for making claims over supposedly uninhabited territory, such as Australia, which was actually inhabited by aboriginal peoples.

- Res communis: Items that (1) may not be appropriated (claimed as private property); and (2) use rights belong equally to everyone. For an example they cite, "the high seas, res communis omnium, as something that cannot be claimed as individual property, since its use for fishing as an example must be open to everybody. Although the sea cannot be appropriated, fish in the sea become private property after they are caught. Similarly, even if mineral ownership rights were communal, minerals could become private property after being removed from the ground.

"Res Publica were the property of the state and usable by individuals by reason of their membership of the body politic" ([30], p. 75). This statement may be a key to understanding the resource 
curse. In undemocratic or authoritarian states, individual members of the public are definitively not members of the body politic, since they are not ruled by consent, and have no voice in the rule of government. Therefore, it may be that allocating mineral title to the state in these cases contributes to the resource curse, because the public is left out of the decision-making process. If there was an international standard applicable to mineral ownership globally, perhaps some progress could be made. The Extractive Industries Transparency Initiative (EITI) does not contain any provisions about ownership of mining titles or rights, only the transparency of revenue.

Res universitatis are described as "Things belonging to a community, not to individuals, are for instance, those in cities-theatres, stadia, and the like and anything else which is the common property of the community" ([30], pp. 65,75). This may come closest to describing the economic commonwealth. This also conforms to common pool resources as defined by Ostrom, which are managed by small communities. Defining the boundaries of the community is a considerable task. Therefore, in the Institutes of Justinian we have a clear precedent for all forms of property. including the subtle distinctions between res nullius, res communis, and res universitatis.

\subsection{British Civil and Common Law}

The definitive authority on British Law is found in the commentaries on British law written by Sir William Blackstone from 1765-1769. Blackstone asserted that all of British law was derived from Roman Law as compiled by lawyers, such as Tribonian, in the 6th century ([38], pp. 55-56). Many writers, such as Ryan, identify the origins of British civil and common law in the Institutes of Justinian, "The Romans had a great legal system, and much of our present day law, including mining law, had its origins in Roman law ([39], p. 104)".

\subsection{Ad Coelum Doctrine}

Although Roman Law established the rights of minerals to the state, British common law evolved under the doctrine of "Cuius est solum, eius est usque ad coelum et ad infernos" (Latin: "whoever's is the soil, it is theirs all the way to Heaven and all the way to hell"). This doctrine is also known as the ad coelum doctrine, traced to the glossator Accursius in the 1200s, included in Blackstone's famous commentaries on English law, and becoming influential in American law [40]. By comparison, most countries in the world, including British Commonwealth countries, allocate mineral title to the state (or crown), and not to individuals. The principle of using minerals for the common good was enunciated by Lindley, "they are by nature public property, and that they are to be used and regulated in such a way as to conduce most to the general interest of society ([35], pp. 21-22)." Through the ad coelum doctrine, the US allows individual landowners in some jurisdictions to own subsurface rights as well. This is only the case in a few countries around the world.

\section{Communal Property Rights in Western Thought}

\subsection{Locke's Proviso}

The most prominent legal doctrine regarding land in Western thought is probably "Locke's proviso", that individual property rights are legitimate, "at least where there is enough, and as good, left in common for others [41]." If all property is owned then there is no more land left in common for those who do not own land. This concept is very problematic in a full world, where most of the land and minerals are already are owned by someone.

\subsection{Paine's Justification for Communal Ownership of the Earth}

A much more satisfying definition of property is in Thomas Paine's essay entitled "Agrarian Justice". This essay was submitted to the French authorities after the revolution in response to an essay written by a priest, entitled, "The Wisdom and Goodness of God in having made both Rich and Poor". In this essay Paine asserts that poverty is manmade, not god made, and there are two kinds of property, 
natural and artificial property; the product of labour, "it is the value of the improvement only, and not the earth itself, that is individual property" ([10], pp. 6-7).

Paine proposed creating a fund to pay every person 15 pounds sterling upon reaching the age of twenty-one, as a payment for the loss of his or her share of the Earth due to the introduction of private property. Paine also proposed additional payments to people when they reach the retirement age of 50, and those who are lame or blind and thereby unable to work. This essay is often credited as proposing the first social security scheme, the first disability payments, and the first description of a system of dividends from common ownership of property that became embodied in the Alaska Permanent Fund dividend. He makes the claim that the Earth, itself, is common property, and those who displace others from using it must compensate them for their loss. He is essentially saying the entire Earth is the "common heritage of mankind", and those who have been excluded should be compensated.

\subsection{Governing the Commons}

Eleanor Ostrom was the foremost analyst on the governance of common pool resources, especially her book Governing the Commons [42], for which she won the Swedish Reich Bank prize for economics in honour of Alfred Nobel. She asserts that governance of common resources was carried out successfully by many communities historically, in contradiction to Garret Hardin's essay about the "Tragedy of the Commons". Hardin's story of overuse of a grazing pasture for cows took the form of an open access regime or res nullius, rather than res communis or res universitatis, with laws governing their use. Ostrom's common pool resources do not fall in the category of res communis, because they are not accessible to everyone, only members of the community. Therefore, they are more appropriately categorized as res universitatis. The communities described by Ostrom were on a small scale, and the challenge is to scale the management of common resources up to a larger scale, and to maintain environmental and social sustainability.

\subsection{The Public Trust Doctrine}

The Public Trust Doctrine is a pertinent body of common law as it originates in the Magna Carta and the Law of the Forest in 1215-1217 enumerating rights of the barons, as opposed to the king. Extensive literature is available since the seminal work of Joseph Sax including [36,43-45]. The public trust has historically been applied mainly to resources in environmental law that are subject to degradation, such as clean air and water. They also apply to traditional common access to seashores, rivers, forests for gathering and hunting, and other res communis resources. Vermont Senate Bill S.44 in 2008 also included minerals in the calculation of the value of these public trust resources [46].

\section{Contemporary Mineral Title Regimes}

\subsection{Supra-National Communal Ownership Regimes: International Law, Law of the Sea, Antarctica, and Space Law}

While most countries allocate mineral title to the state, it is in international law, space law, seabed law, and native title law that we find the most explicit description of communal, rather than national or private rights, including the "common heritage of mankind" principle. In addition to ancient Roman law, this area of law may contain the greatest precedent for understanding the principles of common ownership in contemporary legal systems.

A number of books and articles are available discussing property rights in previously unclaimed areas including [37,47-52], and others. Since they had not been previously subject to national or private appropriation, they can provide great insight into potential common property regimes that could be applied to the commonwealth of domestic minerals. These property regimes include:

- Common Heritage of Mankind Principle,

- High Seas (Convention on the High Seas, 1958),

- Deep seabed (ISA, 1994 and UNCLOS III), 
- Antarctica (Treaty 1959),

- Outer Space (Outer Space Treaty, 1967),

- Moon (Moon Agreement, 1984),

- Geo-synchronous orbital slots (ITU, ITC),

- UN International Law Concepts or Principles.

\subsubsection{Common Heritage of Mankind (CHM) Principle}

There are four essential elements defining this new principle ([37], p. 1):

(1) The area under consideration cannot be subject to appropriation;

(2) All countries must share in the management of the region;

(3) There must be an active sharing of the benefits reaped from the exploitation of the area's resources; and

(4) The area must be dedicated to exclusively peaceful purposes

This new principle in international law remains very controversial and the meaning is disputed. The main intent is that the benefits, financial and otherwise, from valuable resources in new territories should be shared by all countries, whether they have the technology to access them or not. In practise, I see no difference between CHM and the Roman concept of res communis.

\subsubsection{High Seas (Convention on the High Seas, 1958)}

The high seas are subject to the principle of res communis, since the convention states that the high seas are available to all countries, but no government can legally claim (appropriate) them, which would be the case if they were res nullius ([37], p. 314, note 34). The high seas are so large that they are virtually non-rival, meaning one person's use does not leave less for anyone else. Nor are they excludable, meaning one person may not exclude others from using it. Non-excludable and non-rival is the definition of a pure public good in economics.

\subsubsection{Deep Sea Bed (ISA, 1994 and UNCLOS III)}

The International Seabed Authority (ISA) administers seabed resources which are considered to be "the common heritage of mankind" and not vulnerable to claims of ownership by governments. Minerals in the international area and benefits are supposed to accrue to mankind as a whole without discrimination ([47], p. 695). This is subject to much dispute, but currently the deep seabed is managed as the common property of all humankind by the International Seabed Authority (ISA), and this is primarily for the collection of seabed minerals.

\subsubsection{Antarctica (Treaty 1959)}

The Antarctic Treaty of 1959 set aside the southern polar region for scientific research and environmental protection. Prior to the treaty, seven countries made claims of ownership over territory in the Antarctic, and the treaty freezes the claims of these countries, although not denying them ([47], p. 696). Twelve countries were originally parties to the agreement, which now has 52 parties to the treaty, and 29 voting members [53]. Voting rights are determined by the criteria of having substantial Antarctic research and a permanent facility located in the Antarctic, which could be referred to as a "skin in the game".

The CHM principle has not been extended to the Antarctic, and can probably be explained by the fact that Chile and Argentina have both asserted claims to Antarctic territory ([37], p. 331). In 1988, a convention for mining called the Convention on the Regulation of Antarctic Mineral Resources (CRAMRA) was created, allowing for government-supported mining activities with environmental protection. However, France and Australia refused to ratify it, so the treaty failed. A new protocol prohibits consideration of commercial mining until 2048 ([48], p. 132). 


\subsubsection{Outer Space (Outer Space Treaty, 1967)}

The Outer Space Treaty differs slightly from other similar regimes. Article I uses the wording "province of all mankind" which differs from CHM language ([51], p. 154). However, recently the Congress of the United States passed the Space Resource Exploration and Utilization Act of 2015, which makes private property claims to outer space objects. This seems to conflict with the Outer Space Treaty of 1967 which says the Moon and 'other celestial bodies' cannot be claimed by governments [54]. This emphasizes the traditional American reliance on the ad coelum doctrine of individual property rights. However, the Asteroid Bill explicitly states that companies cannot claim sovereignty over asteroids or appropriate them, but only have use and extraction rights and, therefore, are consistent with the Outer Space Treaty. This is consistent with res communis, rather than res nullius.

\subsubsection{Moon (Moon Agreement, 1984)}

The Moon Treaty has more specific language regarding appropriation than the Outer Space Treaty:

"[n]either the surface nor the subsurface of the moon, nor any part thereof or natural resources in place, shall become property of any State, international intergovernmental or non-governmental organisation, national organisation or non-governmental entity or of any natural person (Article 11.3)" ([52], p. 63).

This leaves much less leeway for interpretation, and Pop claims that is the reason the Moon Treaty has not been universally accepted, while the Space Treaty has a better record of ratification.

\subsubsection{Geo-Synchronous Orbital Slots-International Telecommunication Union (ITU), International} Telecommunication Convention (ITC)

Geo-synchronous satellite orbits cannot be subjected to either res nullius or res communis principles due to signal interference and possibly satellite collision. If they were res nullius, then under open access anyone could appropriate unclaimed satellite slots leading to competition and chaos. Under res communis allowing open access to satellite slots, even without "appropriation", would result in problems because they are rival goods, since there are a restricted number of slots. Occupation of a geo-synchronous orbit amounts to appropriation in practice. Thus, a management regime has been created under the ITU and ITC assigning rights both on a priori (quotas by nation) and a posteriori (first come-first serve) basis ([47], p. 703), but conflicts continue with various national claims.

\subsubsection{UN International Law Concepts or Principles}

There is wording in international law that resources rightly belong to "peoples" and not to states or nations. Nations can often mismanage national resources with little regard to the abject poverty facing their compatriots ([55], p. 259). Majinge also informs us "the right to self-determination and how to freely dispose of natural resources is a right of peoples not of states according to article 1(2) of the two United Nations human rights Covenants of 1966. The provision prescribes rights to natural resources for "all peoples" and not to governments ([55], p. 260).

Pereira and Gough also cite UN documents to assert the right of peoples as opposed to states. They cite the 1962 Resolution on Permanent Sovereignty over Natural Resources (RPSNR), Article 1 of the International Covenant on Civil and Political Rights ('ICCPR'), and article 1 of the International Covenant on Economic, Social and Cultural Rights ('ICESCR'), which all confirm peoples' rights to self-determination ([56], p. 459).

The mining industry is currently implementing concepts, such as social license to operate, and free, prior, and informed consent (FPIC) of local communities. Since these principles are not found in domestic law, they are more of an international standard. They are motivated by the same concerns for fairness that are found to be universal. "The principle of FPIC is found in the UN Declaration on the Rights of Indigenous Peoples (UNDRIP)." Article 10 states: 
"Indigenous peoples shall not be forcibly removed from their lands or territories. No relocation shall take place without the free, prior and informed consent of the indigenous peoples concerned and after agreement on just and fair compensation and, where possible, with the option of return."

Articles 11, 19, 28, and 29 also explicitly use the term FPIC [57].

\subsection{Sub-National Communal Ownership Regimes}

\subsubsection{Australian Communal Native Title}

In the arena of native title there are numerous cases globally and in Australia describing the concept of communal native title. Judge Blackburn in the Milirrpum case, although finding no prior concept of native title in Australian law, did define numerous principles later incorporated into native title. He referred to the case of Geita Sebea v. Territory of Papua, which was Australian territory at the time. The case established that the ownership of the native lands was a "communal usufructuary occupation with a perpetual right of possession in the community" ([11], pp. 52-53). Thus, although Blackburn did not find native title in common law at the time, it had already been recognized by statute in a previous Australian case. Therefore, the principle of communal ownership is not alien to common law jurisdictions in the British Commonwealth.

Native interest in their land was described in the Milirrpum case in the following way including the following description of mining: "The right to dig for and use the flints, clays and other useful minerals in the said lands" ([11], pp. 7-8).

It is noteworthy that, in economics, the primary definition of private property is the ability to exclude others from the right to use your property (excludability) for rival goods (your use leaves less for others). In this characteristic, the Rirratjingu and the Gumatj clans appeared to have communal private property rights to their land, including subsoil minerals. Yet, in the later Ward case, the majority found no evidence of native title to the subsurface rights in the traditions and customs of the indigenous community and concluded that native title in Ward did not include ownership of mineral resources despite the contradiction.

Australia was settled under the Justinian doctrine of "terra nullius", meaning that the land was empty or unoccupied, and preceded according to that definition for 200 years until native title was established in the 1992 and 1998 Mabo cases. Legal authorities readily found res (or terra) nullius in Roman law but were unable to locate res communis, res universitatis, res publicae, or any other communal ownership concept. This seems disingenuous. In the recent native title cases, native title is described as "sui generis" or original and unlike anything else. It is not inaccurate that native title is described as sui generis, since native title varies globally. For example, the Merriam people in the Mabo case were gardeners and, thus, have individual use, if not title, of their garden plots, and some African cases established ownership by a chieftain on behalf of all his tribe, so there is a wide variety of native titles. However, hunter-gatherer peoples almost universally hold land communally, and not individually.

\subsubsection{Native Americans}

Extensive literature is available about development and land rights for Native Americans, including [58-64]. What is interesting about Native American mineral rights is that they is similar to Australia, where Native American tribes rarely have actual title to minerals, since reservations are in the form of a trust held by the federal government. Therefore, communal title is more in the form of perception than actual law. However, Native American tribes, like Australian Aborigines, can negotiate payments for use of their lands for mining, and some tribes have more extensive ownership rights [64], p. 10).

\subsubsection{Canadian First Nations}

In the Canadian territory of Nunavut, native Inuit (first peoples) have settled a single comprehensive land claim. If subsurface rights are also owned, $100 \%$ of royalties belong to the 
tribe [65]. The Dogrib (Tlicho) people negotiated a fee simple title (including minerals) self-government agreement [66]. For Canadian aboriginal groups there is often crown ownership on land reserved for natives, surface ownership, and subsurface rights. There are treaties, land claim settlements, and self-governing agreements. Thus, there are a variety of different ownership regimes for Canadian tribes.

\subsubsection{Royal Bafokeng Nation}

The case of the Royal Bafokeng Nation (RBN) in South Africa is quite extraordinary. In the late 1800s under the leadership of Chief Mokgatle, the tribe was able to purchase legal title deeds to their land ([67], p. 62). In 1920, one of the largest platinum finds on Earth was discovered on Bafokeng land, and it was later developed by mining companies starting in the 1960s. The Bafokeng fought many battles through the apartheid era and after to retain rights to their land and minerals. A landmark case in 1999 finally gave them legitimate compensation of $22 \%$ of mining company net income for minerals on their land and other benefits ([68], p. 45). Throughout their existence, the Bafokeng maintained communal title. By careful management of mining revenue, the Bafokeng have earned the title of "The Richest Tribe in Africa" [68]. The RBN can provide a case study of successful communal title to minerals.

\subsubsection{Alaska Permanent Fund Dividend}

In the case of the Alaska Permanent Fund dividend, a sovereign wealth fund was created from oil royalties on state land starting in 1979 and written into the state constitution. Later, a legislative statute was written that mandated using revenue from interest payments on the fund as a per capita dividend to every resident of Alaska. This dividend system typically pays each resident of the state $\$ 1000-\$ 2000$ per year from interest on the Permanent Fund (Figure 1). This payment has been credited with reducing inequality and poverty in the state of Alaska, and is considered as a model for other countries to follow [9]. This is one of the few cases, which de facto establishes communal rights to the resources of the state as opposed to individual or state rights. The state funds $80 \%$ of its state budget from oil, so is also receiving revenue, but the profit of the permanent fund is allocated directly to the people.

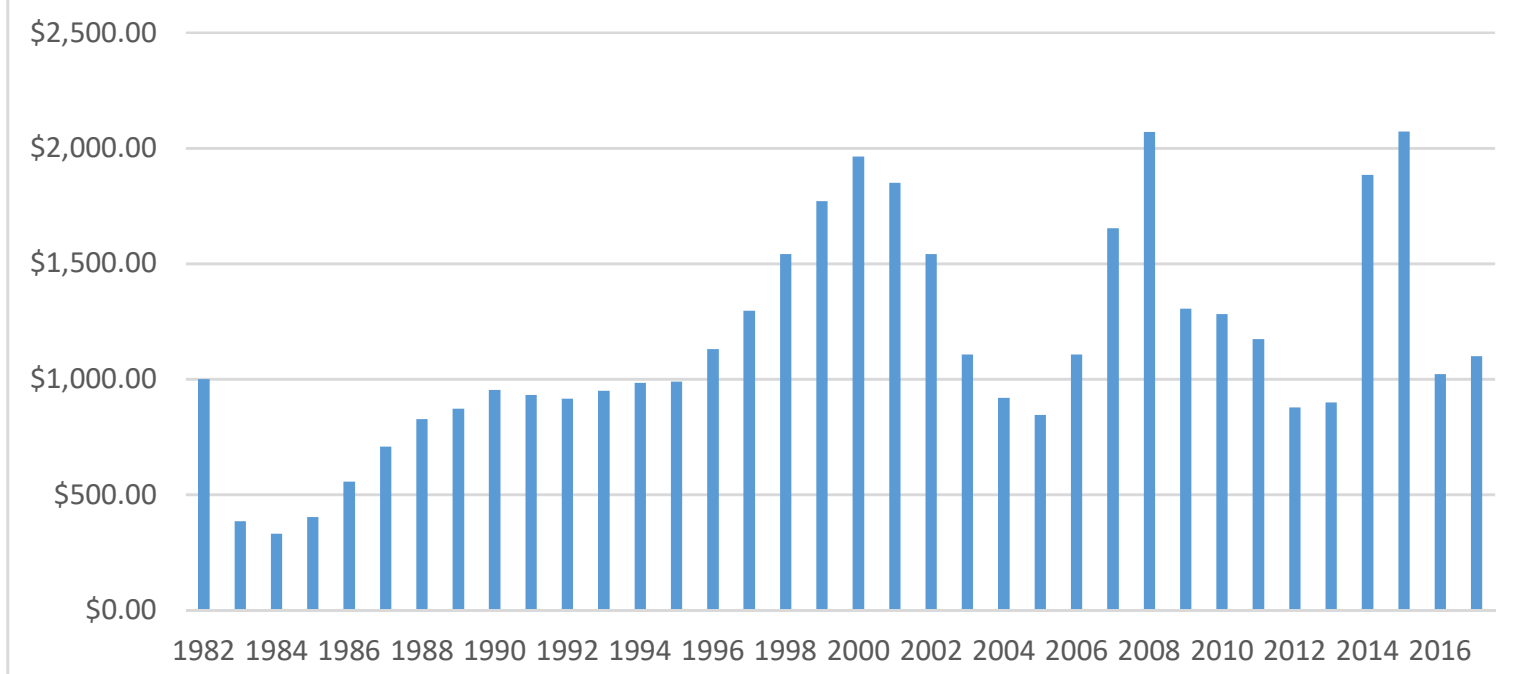

Figure 1. Alaska dividend amounts per year (chart by author from original data) [69].

Angela Cummine, in her book entitled "Citizens' Wealth", discusses the issue of whether mineral wealth belongs to the state or to the citizenry. Regarding Sovereign Wealth Funds (SWFs), typically 
derived from minerals, she writes, " ... vagary dogs the question of whether SWF assets are primarily the property of states or citizens, causing confusion, competition, and conflict within numerous SWF-sponsor communities. Moreover, these squabbles occur irrespective of how democratic the government is that is managing those sovereign funds, suggesting a fundamental uncertainty about the ownership status of sovereign wealth itself" ([70], p. 10).

She reports on a legal case in Alaska in the 1980s when the citizenry sued the state for ownership rights to the state's sovereign wealth. Cummine notes that the courts treated the State and Alaska citizens as separate and competing entities for ownership of mineral wealth. The courts wrestled with the question of who was the rightful owner, the people or the state, administering resources on the people's behalf. The appellate court ultimately decided the case on behalf of the state citing, "language in the Alaska Constitution referring to the state as owner of Alaska's natural resources" ([70], p. 37). Note the determination of the case based on the ultimate mineral title granted to the state in the Alaska Constitution. This bolsters the argument that ultimate title to minerals is crucial in the determination of who benefits from minerals, the government or citizens.

Cummine recommends amending the Santiago Principles for SWFs to achieve citizen-ownership of sovereign wealth, and transforming "sovereign funds into community funds, funds run by the people, for the people" ([70], p. 16). This would also enhance the sustainable development goals of ICMM.

\subsection{National Mineral Title Regimes}

\subsubsection{Compilation of National Mineral Title Laws}

In order to understand the current property regimes for mining countries globally it was necessary to construct a table of mining title laws in all nations (Appendix A). Mineral title laws were taken from national constitutions or mining laws for 199 nations of the world. Many were found at the Comparative Constitutions Project [71], the Extractive Industries Sourcebook [72], and the writings by James Otto [73-76]. These mining titles were then separated into the following categories, which I created to explain mineral ownership according to the constitutions and laws of each country:

$0 \quad$ No minerals

1 President or Ruler

2 State or Crown

3 Communal (People/Common/Collective)

4 "Customary" Landowners

5 Decentralized/Mixed

6 Claimant/Ownerless/Landowner

Explanation: Some states have no minerals and were listed as "No Minerals". This was straightforward. Five, mainly African, countries give mineral titles to the "President" or "Ruler". This was clearly stated in the law books. In many other cases wording was ambiguous. For example, in Indonesia the law states that minerals, "shall be controlled by the State and exploited to the greatest benefit of the people" [77]. Since the state is named as the primary agent, Indonesia was listed under the category of state/crown. The vast majority of countries (142) retain title to ownership of minerals by the state, or "crown". Only in Iceland, Latvia, and Lebanon are mineral titles exclusively given to landowners.

In the case of Vietnam the law states that minerals are: "property invested and managed by the State are public properties, coming under ownership by the entire people represented and uniformly managed by the State" [78]. In this case ownership is twice stated as belonging to "the entire people and being "public properties", and also twice stated as being "managed by the state". Therefore, Vietnam was put in the category of "Communal". Algeria asserts collective mineral titles; Ethiopia and South Africa assert "common" mineral titles, and a total of 19 countries grant titles to the "people", 
the "public", "national community", or the "public domain". I have categorized all these as communal or common ownership according to the words on the pages of law. The goal was to interpret to the greatest extent possible what the meaning of the legal passage was, and the intent of the authors. Upon further research using the United States Geological Survey summary of each country [79], we find that the words on the page do not correspond to any real form of communal ownership, and are, in practice, no different than national ownership. The results of the HDI analysis supports this conclusion.

Numerous Pacific islands grant mineral titles to "customary landowners" which may or may not be communal, such as Bougainville, Vanuatu, Kiribati, Micronesia, Nauru, Marshall Islands, Tuvalu, and Palau. For example, in the case of Nauru, land ownership is private by family and not communal. The Merriam Islanders, where the famous Australian "Mabo" native title case originated, are gardeners and have individual plots, while mainland Aboriginal tribes mainly held land communally. Some Pacific islands had laws stating that minerals belong to "landowners" and some to "customary landowners". Since the cultures are similar, they were all categorized as customary landowners.

The UK, US, Canada, Australia, and a few others have mixed or ambiguous systems of ownership, being divided between the state and smaller subdivisions, such as canton, province, or region, and extending to claimants, and landowners. These were categorized as decentralized $/ \mathrm{mixed}$.

In eight cases, there was no mention of the state or government as the owner, merely as the registrar of claims for landowners or claimants. These were categorized as claimant/ownerless/landowner. Finland, Germany, Korea, Singapore, and Sweden were unique in minerals being essentially ownerless until found by a claimant. The claimant is then granted mineral rights by the state. In Finland this is referred to as "everyman's right".

\subsubsection{Myanmar-Mineral Ownership in an Authoritarian State}

Quoting from a recent article about Myanmar, Andrew Bauer and Maw Htun Aung of NRGI state, "Today, approximately 99 percent of official oil, gas and mining revenues are collected by the national government or state-owned entities, as prescribed by the 2008 constitution" [80]. This follows Ross's definition of a "rentier-state" receiving resource rent independent of, and not accountable to, the public. The lack of benefits to resource-rich regions exacerbates ethnic conflicts in the various regions, such as Kachin, Kayah and Tanintharyi. Bauer and Aung advocate greater sharing of resource wealth at a decentralized level as key elements of peace-making [80].

Since minerals are the property of the state, and $99 \%$ of "official" revenue has been received by the state, it is not surprising that conflict has ensued from the sense of injustice over use of revenue.

\subsubsection{Examples of Communal Ownership at the National Level}

\section{Mongolian Mining Stock Ownership}

Mongolian mineral law grants mineral title to "the people under state protection". Consistent with that principle, every citizen of Mongolia was granted 1072 shares in the mine at Oyu Tolgoi (Figure 2). There is currently no dividend being generated by the project, but may in the future. Mongolians were also granted some cash from mining activities in the past [81], although the results were ambivalent. Through this universal share in a mine and previous payments from minerals, the state recognizes the communal property rights of its citizens to minerals.

Bougainville-Individual Payments

Due to the devastating civil war which had the largest number of fatalities in the Pacific region since WWII, estimated at 10-20,000, there is substantial literature on Bougainville, including [82-85], and others. The island has a system of matrilineal land inheritance, and communal "customary" landownership. Violation of these principles, and retention of $98 \%$ of mining royalties by the 
central Papua New Guinea government, are said to be some of the proximate causes of the civil war. In the Bougainville case, according to Professor Ciaran O'Faircheallaigh, of Griffith University, Australia, payment of mining royalties to an individual landowner who did not share the revenue with other communal owners, resulted in that person being the first person murdered in the civil war [86].

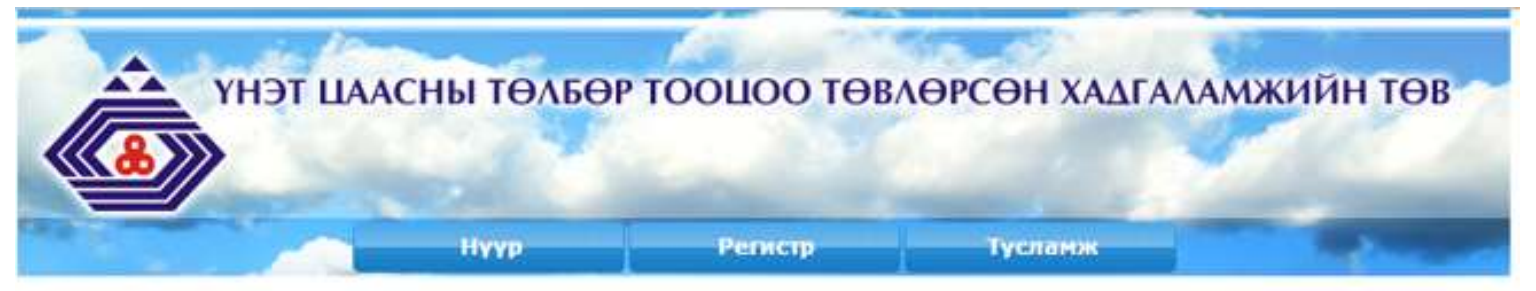

Та регистрын дугаараа оруулна уу. /Регистрийн дугараыг зевхен криллээр бичих естойг анхаарна уу./

\section{Xañx}

Иргэн Та Монгол Улсын Застийн Газраас олгосон "Эрдэнэс тавантолгой" ХК -ийн 1072 ширхэг хувьцаа эзэмшигчэр бүртгэгдсэн байна.

Та Төвлерсен хадгаламжинд данс нээлгээгүй байна. Хэрэв та дансаа нээлгэхийг хүсвэл энэ цахим хуудсыг ашиглан Брокер Дилерийн Компаниудын Мэдээллийг авч уйлчлүүлнэ үү.

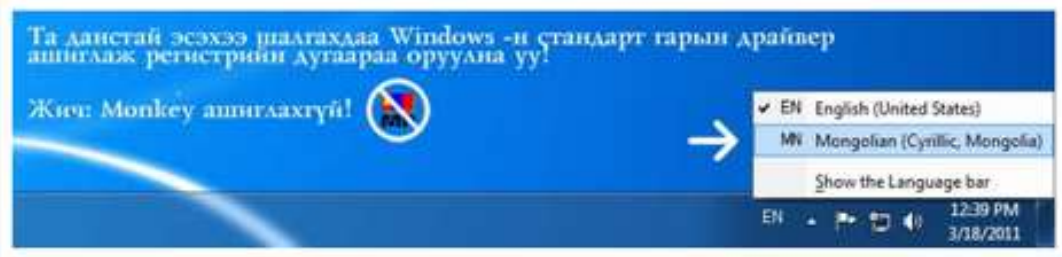

Figure 2. Mongolian Public Mineral Stock certificate (from a Mongolian citizen).

\section{Nauru-Customary Landowners}

The island nation of Nauru is a unique case. People on Nauru fished, farmed, and gathered coconuts prior to occupation by foreign colonists. A valuable mineral was found, leading foreign powers to take control of the resource. Nauru had one the world's largest and most valuable deposits of phosphates, prior to depletion. After attaining independence in 1968, they were able to obtain substantial royalties for the resource totalling $\$ 3.6$ billion (in 2000 dollars) by 2002. In 1975, Nauruans had a per capita GDP of $\$ 50,000$, exceeded only by Saudi Arabia at the time. Nauruans now suffer catastrophic conditions of child malnutrition and anaemia. More than half the population smokes cigarettes. Violence against women due to alcohol is widespread. Eighty-two percent are overweight leading to a quarter of adults having diabetes and $53 \%$ for women over fifty-five. Life expectancy is only fifty-six for men and sixty-five for women [87]. A more extreme example of the resource curse could hardly be found.

\subsubsection{Human Development Index Evaluation}

In order to evaluate the impact of mineral ownership at the national level, a correlation was performed with the 2014 Human Development Index (HDI) for the categories of mineral ownership (Table 1). The sample sizes are too small, so statistical significance cannot be determined by comparing different ownership regimes. However, some basic trends can be perceived from these correlations. The first interesting finding is that countries with no minerals fared better than many of the others, with a mean HDI of 0.748 . This is consistent with the idea that resources are often a curse if governance is corrupt. Countries with the least accountability to the population, which presumably are the 
countries where a President or Ruler controls the minerals, had the worst HDI of 0.595 . This is only five cases, so perhaps is not a robust result.

Table 1. Summary of mineral title regimes and HDI.

\begin{tabular}{cccc}
\hline Type of Ownership & CODE & Mean HDI 2014 & \#n \\
\hline No minerals & 0 & 0.748 & 7 \\
President & 1 & 0.599 & 4 \\
State/crown & 2 & 0.673 & 143 \\
People (common, communal) & 3 & 0.683 & 19 \\
customary (traditional) landowners & 4 & 0.651 & 8 \\
Decentralized/mixed & 5 & 0.851 & 10 \\
Claimant/landowner & 6 & 0.875 & 8 \\
\hline
\end{tabular}

Customary landowners had the third lowest HDI of 0.651 , but this only represents eight Pacific Island countries, which are mainly underdeveloped. The most robust result is the HDI of 0.650 for 142 countries that have state or crown mineral title, which is essentially tied for the second lowest outcome. This supports the contention that giving mineral title to the national government leads to the resource curse, except where governance is good.

In the 19 cases where laws indicated "communal" ownership the HDI was 0.683, which was only slightly higher than the national case. This supports the finding that in reality, saying that the "people, public, or communal society" owns the minerals means nothing in practice, and it is actually the same as government ownership. As mentioned above, United States Geological Survey reports on countries with "communal" ownership [79], reveal that in practice, it is no different than state ownership, and is merely legal rhetoric. Therefore, it was not possible to analyse the difference between communal and other forms or ownership, because communal ownership is essentially non-existent at the national level.

Where there was a decentralized/mixed system of mineral ownership the HDI was the second highest at 0.851 . The best outcome turned out to be where individuals or claimants have mineral titles with an HDI of 0.875 . This supports De Soto's contention that individual property titles have the best development outcome. Luong and Winthal also suggest that domestic private ownership would help reduce conflict [4].

\subsubsection{Analysis of Decentralized versus Centralized Ownership}

Due to the fact that the sample sizes were too small, and the communal category was meaningless, the data was aggregated into larger categories to test a hypothesis related to communal ownership, which is the difference between centralized and decentralized mineral ownership. Decentralized ownership may achieve benefits by distributing mineral governance and revenues more widely in society. An Independent Samples $t$-Test (difference of the means) was conducted using SPSS software (IBM, Armonk, NY, USA), to determine if the mean HDI of countries with decentralized mineral ownership is statistically better than countries with centralized ownership. "The Independent Samples $t$-Test compares the means of two independent groups in order to determine whether there is statistical evidence that the associated population means are significantly different. The Independent Samples $t$-Test is a parametric test [88]." SPSS conducts two different tests, with equal variances assumed and not assumed. The equations are as follows [88]: 
Equal Variances Assumed

When the two independent samples are assume to be drawn from populations with identical population variances (i.e., $\sigma_{1}{ }^{2}=\sigma_{2}{ }^{2}$ ), the test statistic $t$ is computed as:

$$
t=\frac{\bar{x}_{1}-\bar{x}_{2}}{s_{p} \sqrt{\frac{1}{n_{1}}+\frac{1}{n_{2}}}}
$$

with

$$
s_{p}=\sqrt{\frac{\left(n_{1}-1\right) s_{1}^{2}+\left(n_{2}-1\right) s_{2}^{2}}{n_{1}+n_{2}-2}}
$$

where

$\bar{x}_{1}=$ Mean of first sample

$\bar{x}_{2}=$ Mean of second sample

$n_{1}=$ Sample Size (i.e., number of observations) of first sample

$n_{2}=$ Sample Size (i.e., number of observations) of second sample

$s_{1}=$ standard deviation of first sample

$s_{2}=$ standard deviation of second sample

$s_{p}=$ pooled standard deviation

Equal Variance Not Assumed

When the two independent samples are assume to be drawn from populations with unequal variances (i.e., $\sigma_{1}^{2} \neq \sigma_{2}^{2}$ ), the test statistic $t$ is computed as:

$$
t=\frac{\bar{x}_{1}-\bar{x}_{2}}{\sqrt{\frac{s_{1}^{2}}{n_{1}}+\frac{s_{2}^{2}}{n_{2}}}}
$$

where:

$\bar{x}_{1}=$ Mean of first sample

$\bar{x}_{2}=$ Mean of second sample

$n_{1}=$ Sample Size (i.e. number of observations) of first sample

$n_{2}=$ Sample Size (i.e. number of observations) of second sample

$s_{1}=$ standard deviation of first sample

$s_{2}=$ standard deviation of second sample

The calculated $t$ value is then compared to the critical $t$ value from the distribution table with degrees of freedom:

$$
d f=\frac{\left(\frac{s_{1}^{2}}{n_{1}}+\frac{s_{2}^{2}}{n_{2}}\right)^{2}}{\frac{1}{n_{1}-1}\left(\frac{s_{1}^{2}}{n_{1}}\right)^{2}+\frac{1}{n_{2}-1}\left(\frac{s_{2}^{2}}{n_{2}}\right)^{2}}
$$

and chosen confidence level. If the calculated $t$ value $>$ critical $t$ value, then we reject the null hypothesis.

Results

The difference of the means was compared using the following data: the mean of categories 1 , 2 , and 3 were compared to the mean of categories 4, 5, and 6, combined. The first three categories (President, State/crown, communal) are categorized as "centralized" ownership. This is listed as CODE 1 in the independent $t$-test results below. The second three categories (customary landowners, 
decentralized/mixed, and claimant/landowner) are defined as "decentralized" and listed as CODE 2 in the results.

The key results are shown in Figure 3 below, and complete results in Appendix B.

\section{T-Test}

[DataSet4] C: \GFlo\PhD \PHD-Papers \Paper2\diff-means2-countries.sav

\section{Group Statistics}

\begin{tabular}{rlr|c|r|c} 
& CODE & \multicolumn{1}{c}{$N$} & Mean & Std. Deviation & \multicolumn{1}{c}{$\begin{array}{c}\text { Std. Error } \\
\text { Mean }\end{array}$} \\
\hline HDI2014 & 1 & 161 & 0.67283 & 0.152011 & 0.011980 \\
\cline { 2 - 7 } & 2 & 25 & 0.80528 & 0.123874 & 0.024775 \\
\hline
\end{tabular}

\begin{tabular}{|c|c|c|c|c|c|c|}
\hline & & \multicolumn{5}{|c|}{ Independent Samples Test } \\
\hline & & \multicolumn{2}{|c|}{$\begin{array}{l}\text { Levene's Test for Equality of } \\
\text { Variances }\end{array}$} & \multirow[b]{2}{*}{$t$} & \multirow[b]{2}{*}{ df } & \multirow[b]{2}{*}{ Sig. (2-tailed) } \\
\hline & & $\mathrm{F}$ & Sig. & & & \\
\hline \multirow[t]{2}{*}{ HDI2014 } & $\begin{array}{l}\text { Equal variances } \\
\text { assumed }\end{array}$ & 2.137 & 0.145 & -4.145 & 184 & 0.000 \\
\hline & $\begin{array}{l}\text { Equal variances not } \\
\text { assumed }\end{array}$ & & & -4.813 & 36.239 & 0.000 \\
\hline
\end{tabular}

Figure 3. Difference of the means test: centralized vs. decentralized ownership.

The result is significant at the $p<0.001$ level. The average for "centralized" mineral ownership was an HDI of 0.673, and for decentralized it was 0.805 , for a difference of 0.132 . A 13-point difference in the HDI is a noteworthy difference, considering that it can be correlated with the single factor of mineral ownership. According to the UN Human Development Reports 0.673 falls in the category of "medium" human development, while 0.805 is in the "very high category". Further statistical work is needed to disaggregate other factors contributing to HDI, but it indicates that ownership is important.

\subsubsection{Why do National Government Claim Mineral Titles?}

The history of government ownership of land and resources is based on a number of historical principles. In western society, initially the Catholic Pope claimed divine authority of all the lands of the world under the principle of Hierocratic Ecclesia stated in the Romanus Pontifex in 1455 [31]. This was rejected during Renaissance humanism and religious authority was replaced by secular authority [31]. The rights of the sovereign (the king) replaced the rights of the Popes. This developed the feudal system of "tenures" vesting all property in the monarch or sovereign, from which we inherit the nearly universal national ownership of minerals today. The national government as the sovereign has replaced the monarch [89].

During exploration of the world, feudal monarchies, such as England, France, Germany, Spain, and many others, followed a number of principles to assert ownership over foreign lands. The first was the principle of "discovery", meaning that the land was empty or "terra nullius" and, therefore, according to Roman law, it was free for the taking. This principle was claimed in Australia, despite the fact that close to one million aboriginal peoples were already living there, and the land was not "empty" [89]. 
Under British Common Law, there were three additional principles for acquiring title to foreign lands, which were "conquest, cession, and occupation [90]". The meaning of conquest is obvious; it is the taking of land by force. Cession means that the existing population "voluntarily" ceded the land to the British, which, in reality, is the same as conquest. Finally, "occupation" is a temporary measure that eventually becomes permanent through annexation. The final principle used to acquire foreign lands is colonization. This is the assertion of land claims over "inferior people" by a superior force through settlement of their land. Assimilation and appropriation of the native people's culture is used as a strategy to colonize land. In North America, this was the principle of "manifest destiny". Thus, in reality, the assertion of mineral titles by national governments over communities is based historically on violence and conquest.

\section{Sense of Fairness-Basis in Ethology and Anthropology}

Do people find government ownership of minerals to be fair? Recent ethology research has found that the sense of fairness extends to primates and other animals, and not just humans. Prof Frans de Waal, in particular, has written numerous books about the evolution of morality and that it is inherent in not only human beings, but also in primates [91]. Other researchers have confirmed the same findings, such as Yamamoto [92]. Therefore, what is found in national laws, often based on the history of conquest, occupation, or settlement, may not seem fair to all citizens. International law in particular is more responsive to the concerns of lesser-developed countries due to their greater numbers in the UN General Assembly.

We see at the international level and the sub-national level that concerns for fairness in distribution of benefits are paramount. The common heritage of mankind (CHM) principle is asserted in nearly every geographical jurisdiction from the deep seabed, to ocean fishing grounds, to satellite orbits, and even to the moon and outer space objects. This means that everyone is entitled to some benefit from natural resources. Such claims are hardly ever made at the national level. At the sub-national level concerning native tribes, first nations, and local communities, there is a great concern for fairness in the distribution of benefits from mining. These concepts include Social License to Operate (SLO), Free, Prior and Informed Consent (FPIC), and the UN Declaration on the Rights of Indigenous Peoples (UNDRIP) concerning relocation and compensation. These principles are mainly applied to international mining corporations but rarely to governments! In national domestic laws, these principles are often lacking since governments claim sovereignty over minerals in most cases, and the right to decide on their use. Undemocratic governments ignore the concerns for fairness that are universal among human beings. It is only recently with the implementation of the Extractive Industries Transparency Initiative (EITI) that governments are starting to be held accountable for reporting their use of mineral funds. However, EITI has no obligations other than reporting requirements.

\section{Overcoming the Resource Curse through Distribution of Revenues and Mineral Titles}

Martin E. Sandbu in 2006 and Paul Segal in 2011 each proposed the distribution of resource rents to the public as a solution to the resource curse. Sandbu proposes a "Natural Wealth Account" which distributes mineral royalties to every citizen from a "Natural Wealth Office". Then the government can tax this rent back at any rate they desire up to $100 \%$ [93]. This theoretically restores the accountability of government due its need for consent of the governed to taxation. Segal proposes a similar scheme where all resource revenues are paid directly to the citizenry through a resource dividend. He estimates that global poverty would be cut in half [94]. Both of these proposals depend on the national government to voluntarily give up direct collection of mineral revenues, and instead pay them directly to citizens. While I agree in principle with these proposals, it would be enhanced if ownership of minerals itself was changed. Governments are not likely to relinquish ownership of minerals voluntarily. If ownership can be decentralized, then the distribution of revenue will follow naturally and legally. Luong and Winthal also suggest that domestic private ownership might reduce conflict, since it would reduce the ability of governments to fund conflicts [4]. Ownership of minerals could 
be changed through an international best practice or development of customary law. If mineral titles do not belong to the state in the first place, it will be more difficult for governments to be corrupted by this unaccountable revenue. If mineral ownership is decentralized and belongs, by law, to the citizenry communally, to citizens individually, or to "claimants" as in the Finnish "every man's right", then development outcomes are likely to be better, and the resource course is more likely to be avoided.

\section{Conclusions}

National government ownership of mineral titles often results in the resource curse, especially in authoritarian states, since leaders have an independent source of income that is not accountable to the population, as we see in Myanmar, Democratic Republic of the Congo, Saudi Arabia, and other autocracies or warlord states. If some individuals are compensated, but not others, such as in the Bougainville case, there may be resentment and conflict generated. States, such as Alaska and Mongolia, have distributed direct benefits or revenue to the public, thereby recognizing some communal ownership rights. There is ample precedent and clear legal history to implement communal titles. Communal title to minerals, and resulting decentralized benefit sharing, may result in less conflict and better development outcomes than either state or individual title to minerals. Analysis conducted here was not able to demonstrate benefits statistically from communal title, per se. However a comparison of means for decentralized versus centralized ownership provides evidence for better results from distributed, decentralized ownership. This would contribute to Angela Cummine's call to "turn sovereign funds into community funds, funds run by the people, for the people ([70], p. 16)." This statement could be expanded to include all mineral revenues, since sovereign funds only receive a small fraction of public mineral revenues, such as $12-15 \%$ in the case of Alaska. Future research by this author will investigate the statistical correlation between mineral titles and the Human Development Index (HDI), in order to disaggregate ownership from other influential factors. Additional factors that could be included in the analysis are corruption perception, level of democracy, transparency, gender gap, resource rent percentage of GDP, resources percentage of exports, resource revenue percentage of government revenue, etc. Understanding the influence of mineral ownership can help create better development outcomes and reduce conflict.

Acknowledgments: The author gratefully acknowledges the financial support of the University of Queensland Centennial Scholarship and the International Postgraduate Research Scholarship. The author gratefully acknowledges the assistance of advisors Saleem Ali and Kathryn Sturman. Detailed contributions by anonymous reviewers greatly enhanced the quality of this article.

Conflicts of Interest: The author declares no conflict of interest.

Appendix A. National Mineral Title Laws

\begin{tabular}{ccc}
\hline Country Total $=\mathbf{1 9 9}$ & Ownership & HDI $\mathbf{2 0 1 4}$ \\
\hline \multicolumn{1}{c}{ No Minerals $\mathrm{n}=\mathbf{7}$} & & \\
Monaco & None &.. \\
Saint Lucia & None & 0.729 \\
Saint Vincent and Grenadines & None & 0.720 \\
Samoa & None & 0.702 \\
San Marino & None &.. \\
Hong Kong, China (SAR) & None & 0.910 \\
Palestine, State of & None & 0.677 \\
& Mean HDI & 0.748 \\
\hline
\end{tabular}




\begin{tabular}{|c|c|c|}
\hline \multicolumn{3}{|c|}{ President/Ruler $n=5$} \\
\hline Zambia & President/state & 0.586 \\
\hline Zimbabwe & President & 0.509 \\
\hline Brunei Darussalam & President/Ruler & 0.856 \\
\hline Ghana & Republic/President/people & 0.579 \\
\hline Malawi & President on behalf of people & 0.445 \\
\hline & Mean HDI & 0.595 \\
\hline \multicolumn{3}{|c|}{ State/Crown $\mathrm{n}=142$} \\
\hline Afghanistan & State & 0.465 \\
\hline Albania & State & 0.733 \\
\hline Andorra & State & 0.845 \\
\hline Angola & State & 0.532 \\
\hline Antigua and Barbuda & Crown & 0.783 \\
\hline Armenia & State & 0.733 \\
\hline Azerbaijan & State & 0.751 \\
\hline Bahamas & State & 0.790 \\
\hline Bahrain & State & 0.824 \\
\hline Bangladesh & State & 0.570 \\
\hline Barbados & State & 0.785 \\
\hline Belarus & State & 0.798 \\
\hline Belize & State & 0.715 \\
\hline Benin & State & 0.480 \\
\hline Bhutan & State & 0.605 \\
\hline Botswana & State & 0.698 \\
\hline Brazil & State & 0.755 \\
\hline Bulgaria & State & 0.782 \\
\hline Burkina Faso & State & 0.402 \\
\hline Burundi & State & 0.400 \\
\hline Cambodia & State & 0.555 \\
\hline Cameroon & State & 0.512 \\
\hline Cape Verde & State & 0.646 \\
\hline Central African Republic & State & 0.350 \\
\hline Chad & State & 0.392 \\
\hline Chile & State & 0.832 \\
\hline China & State & 0.727 \\
\hline Colombia & State & 0.720 \\
\hline Comoros & State & 0.503 \\
\hline Congo-Rep & State & 0.591 \\
\hline Congo-DPR & State & 0.433 \\
\hline Costa Rica & State & 0.766 \\
\hline Cote d'Ivoire & State & 0.462 \\
\hline Croatia & State & 0.818 \\
\hline Cuba & State & 0.769 \\
\hline Cyprus & Crown & 0.850 \\
\hline Czech Republic & State & 0.870 \\
\hline Denmark & State & 0.923 \\
\hline Djibouti & State & 0.470 \\
\hline Dominica & State & 0.724 \\
\hline Dominican Republic & State & 0.715 \\
\hline Ecuador & State & 0.732 \\
\hline El Salvador & State & 0.666 \\
\hline Equatorial Guinea & State & 0.587 \\
\hline
\end{tabular}




\begin{tabular}{|c|c|c|}
\hline Eritrea & State & 0.391 \\
\hline Estonia & State & 0.861 \\
\hline Fiji & State & 0.727 \\
\hline France & State & 0.888 \\
\hline Gabon & State & 0.684 \\
\hline Gambia & Crown & 0.441 \\
\hline Georgia & State & 0.754 \\
\hline Grenada & Crown & 0.750 \\
\hline Guatemala & State & 0.627 \\
\hline Guinea & State & 0.411 \\
\hline Guinea-Bissau & State & 0.420 \\
\hline Guyana & State & 0.636 \\
\hline Haiti & State & 0.483 \\
\hline Honduras & State & 0.606 \\
\hline Hungary & State & 0.828 \\
\hline Indonesia & State to the benefit of the people & 0.684 \\
\hline Iran & State & 0.766 \\
\hline Ireland & State & 0.916 \\
\hline Israel & State & 0.894 \\
\hline Italy & State & 0.873 \\
\hline Jamaica & Crown (mainly) & 0.719 \\
\hline Japan & State & 0.891 \\
\hline Jordan & State & 0.748 \\
\hline Kazakhstan & State & 0.788 \\
\hline Kenya & State & 0.548 \\
\hline Korea (DPR) & State &.. \\
\hline Kosovo & State &.. \\
\hline Kuwait & State & 0.816 \\
\hline Kyrgyz Republic & State & 0.655 \\
\hline Lesotho & State & 0.497 \\
\hline Liberia & State & 0.430 \\
\hline Libya & State & 0.724 \\
\hline Liechtenstein & State & 0.908 \\
\hline Lithuania & State & 0.839 \\
\hline Luxemburg & State & 0.892 \\
\hline Macedonia & State & 0.747 \\
\hline Madagascar & State & 0.510 \\
\hline Malaysia & State & 0.779 \\
\hline Maldives & State & 0.706 \\
\hline Mali & State & 0.419 \\
\hline Malta & State & 0.839 \\
\hline Mauritania & State & 0.506 \\
\hline Mauritius & State & 0.777 \\
\hline Mexico & State & 0.756 \\
\hline Montenegro & State & 0.802 \\
\hline Morocco & State & 0.628 \\
\hline Mozambique & State & 0.416 \\
\hline Myanmar & State & 0.536 \\
\hline Namibia & State & 0.628 \\
\hline Nepal & State & 0.548 \\
\hline Netherlands & State & 0.922 \\
\hline New Caledonia & State &.. \\
\hline New Zealand & Crown & 0.913 \\
\hline
\end{tabular}




\begin{tabular}{|c|c|c|}
\hline Nicaragua & State & 0.631 \\
\hline Niger & State & 0.348 \\
\hline Nigeria & State on behalf of the people & 0.514 \\
\hline Norway & State & 0.944 \\
\hline Oman & State & 0.793 \\
\hline Pakistan & State & 0.538 \\
\hline Panama & State & 0.780 \\
\hline Papua New Guinea & State & 0.505 \\
\hline Paraguay & State & 0.679 \\
\hline Peru & State & 0.734 \\
\hline Philippines & State & 0.668 \\
\hline Poland & State & 0.843 \\
\hline Qatar & State & 0.850 \\
\hline Russian Federation & State & 0.798 \\
\hline Rwanda & State & 0.483 \\
\hline Saint Kitts and Nevis & Crown & 0.752 \\
\hline Sao Tome \& Principe & State & 0.555 \\
\hline Saudi Arabia & State & 0.837 \\
\hline Senegal & State & 0.466 \\
\hline Serbia & State & 0.771 \\
\hline Seychelles & State & 0.772 \\
\hline Sierra Leone & State & 0.413 \\
\hline Slovakia & State & 0.844 \\
\hline Slovenia & State & 0.880 \\
\hline Somalia & State &.. \\
\hline South Sudan & State for the people & 0.467 \\
\hline Spain & State & 0.876 \\
\hline Sri Lanka & State & 0.757 \\
\hline Sudan & State & 0.479 \\
\hline Suriname & State & 0.714 \\
\hline Swaziland & State & 0.531 \\
\hline Taiwan & State &.. \\
\hline Tajikistan & State & 0.624 \\
\hline Tanzania (United Republic of) & State & 0.521 \\
\hline Thailand & State & 0.726 \\
\hline Timor-Leste & State & 0.595 \\
\hline Togo & State/public domain & 0.484 \\
\hline Tonga & Crown & 0.717 \\
\hline Turkey & State & 0.761 \\
\hline Trinidad \& Tobago & State/President & 0.772 \\
\hline Uganda & State & 0.483 \\
\hline United Kingdom & Crown & 0.907 \\
\hline Uruguay & State & 0.793 \\
\hline Uzbekistan & State & 0.675 \\
\hline \multirow[t]{2}{*}{ Yemen } & State & 0.498 \\
\hline & Mean HDI & 0.650 \\
\hline \multicolumn{3}{|c|}{ People/Common/Collective $\mathrm{n}=19$} \\
\hline Algeria & Common/public/collective & 0.736 \\
\hline Bolivia & People and state & 0.662 \\
\hline Egypt & People managed by the state & 0.690 \\
\hline Ethiopia & Common/state/people & 0.442 \\
\hline Iraq & People/regions & 0.654 \\
\hline
\end{tabular}




\begin{tabular}{|c|c|c|}
\hline Laos & National community/state mgmt. & 0.575 \\
\hline Moldova & Public & 0.693 \\
\hline Mongolia & People under state protection & 0.727 \\
\hline Portugal & Public domain & 0.830 \\
\hline Romania & Public/state & 0.793 \\
\hline Solomon islands & People and state & 0.506 \\
\hline South Africa & Common/state custodian & 0.666 \\
\hline Syrian Arab Republic & Public/state & 0.594 \\
\hline Tunisia & Public domain of the state & 0.721 \\
\hline Ukraine & People/state & 0.747 \\
\hline United Arab Emirates & Public & 0.835 \\
\hline Vietnam & $\begin{array}{c}\text { Public/people/managed by the } \\
\text { state }\end{array}$ & 0.666 \\
\hline Turkmenistan & People and state & 0.688 \\
\hline \multirow[t]{2}{*}{ Venezuela } & Public/state & 0.762 \\
\hline & Mean HDI & 0.683 \\
\hline \multicolumn{3}{|c|}{ “Customary" landowners $\mathrm{n}=8$} \\
\hline Marshall Isles & landowners &.. \\
\hline Micronesia & landowner & 0.640 \\
\hline Nauru & landowner & .. \\
\hline Palau & landowner/state & 0.780 \\
\hline Kiribati & customary landowners & 0.590 \\
\hline Bougainville & customary landowners &.. \\
\hline Tuvalu & customary landowners & .. \\
\hline \multirow[t]{2}{*}{ Vanuatu } & customary landowners & 0.594 \\
\hline & Mean HDI & 0.651 \\
\hline \multicolumn{3}{|c|}{ Decentralized/Mixed, $\mathrm{n}=10$} \\
\hline Argentina & Province/canton & 0.836 \\
\hline Australia & $\begin{array}{c}\text { Crown in right of the states, some } \\
\text { landowners }\end{array}$ & 0.935 \\
\hline Austria & mixed: State, claimant, landowner & 0.885 \\
\hline Belgium & Province/regional/claimant & 0.890 \\
\hline Bosnia \& Herzegovina & mixed: federal/Cantons & 0.733 \\
\hline Canada & Crown/Provincial/landowner & 0.913 \\
\hline Greece & mixed: state, claimant, landowner & 0.865 \\
\hline India & states and federal government & 0.609 \\
\hline Switzerland & Province/canton & 0.930 \\
\hline \multirow[t]{2}{*}{ United States } & mixed: State, claimant, landowner & 0.915 \\
\hline & Mean HDI & 0.851 \\
\hline \multicolumn{3}{|c|}{ Claimant/Ownerless $/$ Landowner $\mathrm{n}=8$} \\
\hline Finland & Claimant/ownerless & 0.883 \\
\hline Germany & Claimant/ownerless & 0.916 \\
\hline Iceland & Landowner & 0.899 \\
\hline Korea(Rep) & Claimant/state mgmt. & 0.898 \\
\hline Latvia & Landowner & 0.819 \\
\hline Lebanon & Landowner & 0.769 \\
\hline Singapore & Claimant/ownerless & 0.912 \\
\hline \multirow[t]{2}{*}{ Sweden } & Claimant/landowner & 0.907 \\
\hline & Mean HDI & 0.875 \\
\hline
\end{tabular}




\section{Appendix B. Two-Correlation of Decentralized vs. Centralized Mineral Ownership with HDI}

\section{T-Test}

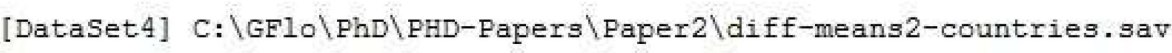

\begin{tabular}{rl|r|r|r|r}
\multicolumn{7}{c}{ Group Statistics } \\
& CODE & \multicolumn{1}{c}{$N$} & Mean & Std. Deviation & $\begin{array}{c}\text { Std. Error } \\
\text { Mean }\end{array}$ \\
\hline HDI2014 & 1 & 161 & 0.67283 & 0.152011 & 0.011980 \\
\cline { 2 - 6 } & 2 & 25 & 0.80528 & 0.123874 & 0.024775 \\
\hline
\end{tabular}

\begin{tabular}{|c|c|c|c|c|c|c|c|c|c|c|}
\hline \multicolumn{11}{|c|}{ Independent Samples Test } \\
\hline & & \multicolumn{2}{|c|}{$\begin{array}{l}\text { Levene's Test for Equality of } \\
\text { Variances }\end{array}$} & \multicolumn{7}{|c|}{ t-test for Equality of Means } \\
\hline & & \multirow[b]{2}{*}{$\mathrm{F}$} & \multirow[b]{2}{*}{ Sig. } & \multirow[b]{2}{*}{$t$} & \multirow[b]{2}{*}{ df } & \multirow[b]{2}{*}{ Sig. (2-tailed) } & \multirow{2}{*}{$\begin{array}{l}\text { Mean } \\
\text { Difference }\end{array}$} & \multirow{2}{*}{$\begin{array}{l}\text { Std. Error } \\
\text { Difference }\end{array}$} & \multicolumn{2}{|c|}{$\begin{array}{l}95 \% \text { Confidence Interval of the } \\
\text { Difference }\end{array}$} \\
\hline & & & & & & & & & Lower & Upper \\
\hline \multirow[t]{2}{*}{ HDI2014 } & $\begin{array}{l}\text { Equal variances } \\
\text { assumed }\end{array}$ & 2.137 & 0.145 & -4.145 & 184 & 0.000 & -0.132448 & 0.031954 & $-\theta .195490$ & -0.069405 \\
\hline & $\begin{array}{l}\text { Equal variances not } \\
\text { assumed }\end{array}$ & & & -4.813 & 36.239 & 0.000 & $-\theta .132448$ & 0.027519 & $-\theta .188247$ & -0.076649 \\
\hline
\end{tabular}




\section{References and Notes}

1. Dictionary.com Dictionary.com. Available online: http://www.dictionary.com/browse/wealth?s=t (accessed on 14 May 2018).

2. Farzanegan, M.R.; Lessmann, C.; Markwardt, G. Natural resource rents and internal conflicts: Can decentralization lift the curse? Econ. Syst. 2018. Available online: https://www.sciencedirect. com/science/article/abs/pii/S0939362518300931 (accessed on 14 May 2018). [CrossRef]

3. Weinthal, E.; Luong, P.J. Combating the Resource Curse: An Alternative Solution to Managing Mineral Wealth. Perspect. Polit. 2006, 4, 35-53. [CrossRef]

4. Luong, P.J.; Weinthal, E. Rethinking the Resource Curse: Ownership Structure, Institutional Capacity, and Domestic Constraints. Annu. Rev. Polit. Sci. 2006, 9, 241-263. [CrossRef]

5. Cawood, F.T.; Minnitt, R.C.A. A historical perspective on the economics of the ownership of mineral rights ownership. J. S. Afr. Inst. Min. Metall. 1998, 98, 369-370.

6. De Soto, H. The Mystery Of Capital, Why Capitalism Succeeds in the West And Fails Everywhere Else, 1st ed.; Basic Books: New York, NY, USA, 2000; p. 288.

7. Wegenast, T.; Schneider, G. Ownership matters: Natural resources property rights and social conflict in Sub-Saharan Africa. Polit. Geogr. 2017, 61, 110-122. [CrossRef]

8. Cleary, P. How Australia Wasted the Mining Boom. Available online: https://johnmenadue.com/paulcleary-how-australia-wasted-the-mining-boom/ (accessed on 15 May 2018).

9. Widerquist, K.; Howard, M. Exporting the Alaska Model: Adapting the Permanent Fund Dividend for Reform Around the World; Palgrave Macmillan: New York, NY, USA, 2012.

10. Paine, T. Agrarian Justice: Opposed to Agrarian Law, and to Agrarian Monopoly; W. Adlard, Rue Menilmontant: Paris, France; Paternoster Row: London, UK, 1797.

11. Blackburn, R.A.; Milirrpum; Territory, N.; Leslie, A.J. Milirrpum v. Nabalco Pty. Ltd. and the Commonwealth of Australia: (Gove Land Rights Case): A claim by Aborigines That Their Interests in Certain Land Had Been Invaded Unlawfully by the Defendents: Judgement of the Honourable Mr. Justice Blackburn; Law Book Co.: Hong Kong, 1971.

12. Sachs, J.D. Warner Natural Resource Abundance and Economic Growth; National Bureau of Economic Research: Cambridge, MA, USA, 1995.

13. Dauvin, M.; Guerreiro, D. The Paradox of Plenty: A Meta-Analysis. World Dev. 2017, 94, 212-231. [CrossRef]

14. Mahdavi, P. Why do leaders nationalize the oil industry? The politics of resource expropriation. Energy Policy 2014, 75, 228-243. [CrossRef]

15. Shambayati, H. The Rentier State, Interest Groups, and the Paradox of Autonomy: State and Business in Turkey and Iran. Comp. Polit. 1994, 26, 307-331. [CrossRef]

16. Ross, M.L. The Oil Curse: How Petroleum Wealth Shapes the Development of Nations; Princeton University Press: Princeton, NJ, USA, 2012.

17. Revenue Watch. 2013 Resource Governance Index; Revenue Watch: New York, NY, USA, 2013.

18. Institute, N.R.G. 2017 Resource Governance Index. Available online: https://resourcegovernance.org/ analysis-tools/publications /2017-resource-governance-index (accessed on 15 May 2018).

19. Economist Intelligence Unit. Democracy Index 2014, Democracy and Its Discontents; Economist Intelligence Unit: London, UK, 2014.

20. ICMM. Sustainable Development Framework: ICMM Principles; International Council on Mining and Metals: London, UK, 2015.

21. Anderson, T.L.; Hill, P.J. Privatizing the Commons: An Improvement? South. Econ. J. 1983, 50, 438. [CrossRef]

22. Barnes, R. Property Rights and Natural Resources; Hart: Oxford, UK; Portland, OR, USA, 2009.

23. Dannreuther, R.; Ostrowski, W. Global Resources: Conflict and Cooperation; Palgrave Macmillan: Basingstoke, UK, 2013.

24. Feder, G.; Feeny, D. Land Tenure and Property Rights: Theory and Implications for Development Policy. World Bank Econ. Rev. 1991, 5, 135-153. [CrossRef]

25. Friedman, A.E. The Economics of the Common Pool: Property Rights in Exhaustible Resources. UCLA Law Rev. 1970, 18, 855.

26. Levine, R. Law, Endowments and Property Rights. J. Econ. Perspect. 2005, 19, 61-88. [CrossRef]

27. Sprankling, J.G. The International Law of Property; Oxford University Press: Oxford, UK, 2014; Volume 1. 
28. Stephenson, M.A. Property. Chapter 22; University of Queensland: St. Lucia, Australia, 2013.

29. Dictionary.com. Available online: http://www.dictionary.com/browse/inalienable?s=t (accessed on 14 May 2018).

30. Thomas, J.A.C. The Institutes of Justinian: Text, translation, and commentary; North-Holland: Amsterdam, The Netherlands, 1975.

31. Williams, R.A. The Medieval and Renaissance Origins of the Status of the American-Indian in Western Legal Thought. South. Calif. Law Rev. 1983, 57, 1.

32. Dobra, J. Divergent Mineral Rights Regimes a Natural Experiment in Canada and the United States Yields Lessons; Fraser Institute: Vancouver, BC, USA, 2014.

33. Jagger, K. Minerals, mining leases and native title. Aust. Min. Pet. Law J. 2002, 21, 236-243.

34. Johnson, E.L. Mineral Rights-Legal Systems Governing Exploration and Exploitation; Royal Institute of Technology (KTH): Stockholm, Sweden, 2010.

35. Lindley, C.H. A Treatise on the American Law Relating to Mines and Mineral Lands within the Public Land States and Territories and Governing the Acquisition and Enjoyment of Mining Rights in Lands of the Public Domain; F.B. Rothman: Littleton, CO, USA, 1988; Volume 3.

36. Rose, C.M. Expanding the choices for the global commons: Comparing newfangled tradable allowance schemes to old-fashioned common property regimes. Duke Environ. Law Policy Forum 1999, 10, 45-72.

37. Larschan, B.; Brennan, B.C. The common heritage of mankind principle in international law. Columbia J. Trans. Law 1983, 21, 305.

38. Blackstone, W.S.; Warren, S. Blackstone's Commentaries: Systematically Abridged and Adapted to the Existing State of the Law and Constitution: With Great Additions; W. Maxwell: London, UK, 1856; Volume 2.

39. Ryan, B. The law surrounding "miner's right": Origin of the Mining Law of Queensland. J. R. Hist. Soc. Qld. Brisbane 1974, 9, 101-114.

40. Blackstone, W.S. Blackstone's Commentaries. Book Two. Chapter 2. p. 18. Available online: http: / / avalon. law.yale.edu/18th_century/blackstone_bk2ch2.asp (accessed on 14 May 2018).

41. Roark, E. Applying Locke's Proviso to Unappropriated Natural Resources. Polit. Stud. 2012, 60, 687-702. [CrossRef]

42. Ostrom, E.; Ebooks, C. Governing the Commons: The Evolution of Institutions for Collective Action; Cambridge University Press: New York, NY, USA; Cambridge, UK, 1990.

43. Sax, J.L. The Public Trust Doctrine in Natural Resource Law: Effective Judicial Intervention. Mich. Law Rev. 1970, 68, 471-566. [CrossRef]

44. Rose, C.M. Joseph Sax and the idea of the public trust. Ecol. Law Q. 1998, 25, 351-362. [CrossRef]

45. Wood, M.C. Nature's trust: Reclaiming and environmental discourse. Va. Environ. Law J. 2007, $25,243$.

46. Farley, J.; Costanza, R.; Flomenhoft, G.; Kirk, D. The Vermont Common Assets Trust: An institution for sustainable, just and efficient resource allocation. Ecol. Econ. 2015, 109, 71-79. [CrossRef]

47. Buxton, C.R. Property in outer space: The common heritage of mankind principle vs. the "first in time, first in right" rule of property law. J. Air Law Commer. 2004, 69, 689.

48. Coffey, S. Establishing a legal framework for property rights to natural resources in outer space. Case West. Reserve J. Int. Law 2009, 41, 119.

49. Zell, J.L. Putting a mine on the moon: Creating an international authority to regulate mining rights in outer space. Minn. J. Int. Law 2006, 15, 489.

50. Leach, M. Property Rights In Outer Space. Scitech Lawyer 2014, 10, 4.

51. Lee, R.J. Law and Regulation of Commercial Mining of Minerals in Outer Space; Springer: Dordrecht, The Netherlands; New York, NY, USA, 2012; Volume 7.

52. Pop, V. Who Owns the Moon?: Extraterrestrial Aspects of Land and Mineral Resources Ownership; Springer: New York, NY, USA, 2009; Volume 4.

53. Nations, U. Antarctic Treaty Parties. Available online: http://www.ats.aq/devAS/ats_parties.aspx?lang=e (accessed on 14 May 2018).

54. Koeber, J. The US Mulls Breaking an International Treaty So Americans Can Mine Asteroids. Available online: https://motherboard.vice.com/en_us/article/4x3m99/the-us-mulls-breaking-aninternational-treaty-so-americans-can-mine-asteroids (accessed on 14 May 2018). 
55. Majinge, C.R. The Doctrine of Permanent Sovereignty over Natural Resources in International Law and Its Application in Developing Countries: The Case of the Mining Sector in Tanzania. Afr. Yearbook Int. Law 2008, 34, 235-268. [CrossRef]

56. Pereira, R.; Gough, O. Permanent sovereignty over natural resources in the 21st century: Natural resource governance and the right to self-determination of indigenous peoples under international law. Melb. J. Int. Law 2013, 14, 451-495.

57. United Nations. Un Declaration on the Rights of Indigenous Peoples, 2007; United Nations: New York, NY, USA, 2007.

58. Niblock, T. The American Indian and Alaskan Native Development Index: The Progress of and Prospects for. Indian Country. Undergrad. Econ. Rev. 2007, 3, 7.

59. Dippel, C. Forced Coexistence and Economic Development: Evidence from Native American Reservations. Econometrica 2014, 82, 2131-2165. [CrossRef]

60. Henson, E.C. The State of the Native Nations: Conditions under U.S. Policies of Self-Determination: The Harvard Project on American Indian Economic Development; Oxford University Press: New York, NY, USA, 2008.

61. Hurst, M. The determinants of earnings differentials for indigenous Americans: Human capital, location, or discrimination? Q. Rev. Econ. Financ. 1997, 37, 787-807. [CrossRef]

62. Necefer, L.; Wong-Parodi, G.; Jaramillo, P.; Small, M.J. Energy development and Native Americans: Values and beliefs about energy from the Navajo Nation. Energy Res. Soc. Sci. 2015, 7, 1-11. [CrossRef]

63. Randall, K.Q.A.; Spilde, K.A.; Taylor, J.B. Social and Economic Changes on American Indian Reservations in California: An Examination of Twenty Years of Tribal Government Gaming1. UNLV Gaming Res. Rev. J. 2014, $18,39$.

64. Grogan, M.; Morse, R.; Youpee-Roll, A. Native American Lands and Natural Resource Development; Revenue Watch Institute: New York, NY, USA, 2011.

65. Government of Canada, Indigenous and Northern Affairs. FAQ about Mining Royalty in Nunavut and the Northwest Territories; Government of Canada, Indigenous and Northern Affairs: Ottawa, ON, Canada, 2018.

66. Government of Canada, Indigenous and Northern Affairs. Tlicho Agreement; Government of Canada, Indigenous and Northern Affairs: Ottawa, ON, Canada, 2018.

67. Cook, S.E. Community management of mineral resources: The case of the Royal Bafokeng Nation. J. S. Afr. Inst. Min. Metall. 2013, 113, 61-66.

68. Mbenga, B.; Manson, A. 'The Richest Tribe in Africa': Platinum-Mining and the Bafokeng in South Africa's North West Province, 1965-1999. J. S. Afr. Stud. 2003, 29, 25-47.

69. Alaska Department of Revenue, Permanent Fund Dividend Division. Summary of Dividend Applications \& Payments. Available online: https://pfd.alaska.gov/Division-Info/Summary-of-Applications-andPayments (accessed on 14 April 2018).

70. Cummine, A. Citizens' Wealth: Why (and How) Sovereign Funds Should be Managed by the People for the People; Yale University Press: New Haven, CT, USA, 2016.

71. Project, C.C. Constitute. Available online: https://www.constituteproject.org/search (accessed on 14 May 2018).

72. EISourceBook. Policy, Legal and Contractual Framework. Available online: http:/ /www.eisourcebook.org/ 642_5PolicyLegalandContractualFramework.html (accessed on 14 May 2018).

73. Otto, J. Mining Royalties: A Global Study of Their Impact on Investors, Government, and Civil Society; World Bank: Washington, DC, USA, 2006.

74. Otto, J.; Cordes, J. The Regulation of Mineral Enterprises: A Global Perspective on Economics, Law and Policy; Rocky Mountain Mineral Law Foundation: Westminster, CO, USA, 2002.

75. Otto, J.M. A national mineral policy as a regulatory tool. Resour. Policy 1997, 23, 1-7. [CrossRef]

76. Otto, J.M. Global changes in mining laws, agreements and tax systems. Resour. Policy 1998, 24, 79-86. [CrossRef]

77. Bastida, E.; Wälde, T.; Warden-Fernández, J. International and Comparative Mineral Law and Policy; Kluwer Law International: Hague, The Netherlands, 2005.

78. Vietnam Vietnam Constitution 1992 (rev. 2013). Available online: https://www.constituteproject.org/ constitution/Socialist_Republic_of_Vietnam_2013?lang=en (accessed on 14 May 2018).

79. Fong-Sam, Y. The Mineral Industry of Vietnam; USGS, US Department of the Interior: Washington, DC, USA, 2017. 
80. Government of Myanmar. Mining Law of 1994; Government of Myanmar: Naypidaw, Myanmar, 1994; Chapter VII.

81. Yeung, Y.; Howes, S. Resources-to-Cash: A Cautionary Tale from Mongolia; Development Policy Centre, Australian National University: Canberra, Australia, 2015.

82. Denoon, D. Getting under the Skin: The Bougainville Copper Agreement and the Creation of the Panguna Mine; Melbourne University Press: Carlton, Australia, 2000.

83. Hermkens, A.-K. Marian Movements and Secessionist Warfare in Bougainville, Papua New Guinea. J. Altern. Emerg. Relig. 2015, 18, 35-54. [CrossRef]

84. Lasslett, K. State Crime on the Margins of Empire: Rio Tinto, the War on Bougainville and Resistance to Mining; Pluto Press: London, UK, 2014.

85. Regan, A.J.; Griffin, H.-M. Bougainville before the Conflict; Pandanus Books: Canberra, Australia, 2005.

86. Ciaran O'Faircheallaigh, G.B.S., phone conversation with Flomenhoft, G., 15 May 2015.

87. Thomas, T. The naughty nation of Nauru; Quadrant Magazine Company, Inc.: Balmain, Australia, 2013; Volume 57, pp. 30-34.

88. Kent State University Libraries. SPSS Tutorials: Independent Samples t Test. Available online: https: / /libguides.library.kent.edu/SPSS/IndependentTTest (accessed on 16 May 2018).

89. Hepburn, S. Feudal tenure and native title: Revising an enduring fiction. Syd. Law Rev. 2005, 27, 49-86.

90. Belmessous, S. Empire by Treaty: Negotiating European Expansion, 1600-1900; Oxford University Press USA-OSO: Cary, NC, USA, 2014.

91. Waal, F.D.; Macedo, S.; Ober, J.; Wright, R. Primates and Philosophers: How Morality Evolved; Princeton University Press: Princeton, NJ, USA, 2006.

92. Yamamoto, S.; Takimoto, A. Empathy and Fairness: Psychological Mechanisms for Eliciting and Maintaining Prosociality and Cooperation in Primates. Soc. Justice Res. 2012, 25, 233-255. [CrossRef]

93. Sandbu, M.E. Natural wealth accounts: A proposal for alleviating the natural resource curse. World Dev. 2006, 34, 1153-1170. [CrossRef]

94. Segal, P. Resource Rents, Redistribution, and Halving Global Poverty: The Resource Dividend. World Dev. 2011, 39, 475-489. [CrossRef]

(C) 2018 by the author. Licensee MDPI, Basel, Switzerland. This article is an open access article distributed under the terms and conditions of the Creative Commons Attribution (CC BY) license (http:/ / creativecommons.org/licenses/by/4.0/). 